\title{
Thermogravimetric Analysis of Char Waste from the Air Gasification of Empty Fruit Bunch Briquette.
}

\author{
Bemgba Bevan Nyakuma ${ }^{1, a}{ }^{*}$, Mojtaba Mazangi ${ }^{1, \mathrm{~b}}$, Anwar Johari ${ }^{1, \mathrm{c}}$, Arshad Ahmad ${ }^{1, \mathrm{~d}}$, Tuan Amran \\ Tuan Abdullah ${ }^{1, \mathrm{e}}$ \\ ${ }^{1}$ Institute of Hydrogen Economy (IHE), Faculty of Chemical Engineering, Universiti Teknologi \\ Malaysia, \\ 81310 UTM Skudai, Johor Bahru, Malaysia.
}

\begin{abstract}
The thermal decomposition behavior of char waste produced from the air gasification of Empty Fruit Bunch (EFB) briquette was examined using thermogravimetric analysis (TGA). A comparison between the thermal decomposition behavior of char waste and EFB briquette is also presented. The results indicate that the char waste produced decreased from $22 \%$ to $18 \%$ with increasing temperature from 600 ${ }^{\circ} \mathrm{C}$ to $700{ }^{\circ} \mathrm{C}$ during gasification. This is due to the effect of high temperatures on the primary char decomposition reactions. It was observed that char degradation occurs in two steps; char degradation I \& II with weight losses of $17 \%$ and $32 \%$ respectively. This showed that only $\sim 50 \%$ char was decomposed during thermal analysis, hence higher temperatures are required to ensure complete decomposition. The TGA curve for EFB briquette showed that complete thermal decomposition of EFB briquette occurs in four stages namely; drying, devolatization, reduction and char degradation. The most significant weight loss $2.51 \mathrm{mg}$ or $49.31 \%$ occurred during devolatization.
\end{abstract}

\section{Introduction}

Gasification is considered a promising route for the valorization of lignocellulosic biomass waste. Typically biomass gasification occurs in four stages; drying, devolatization, char gasification and combustion resulting in the production of syngas $\left(\mathrm{CO}, \mathrm{H}_{2}\right)$ [1]. However biomass gasification also produces char (intermediate product) of the thermochemical conversion process. An overview of the key reactions that occur during gasification is presented in equations 1-8;

$$
\begin{aligned}
& \mathrm{C}+\mathrm{O}_{2} \rightarrow \mathrm{CO}_{2} \\
& \mathrm{C}+(1 / 2) \mathrm{O}_{2} \rightarrow \mathrm{CO} \\
& \mathrm{C}+\mathrm{CO}_{2} \rightarrow 2 \mathrm{CO} \\
& \mathrm{C}+\mathrm{H}_{2} \mathrm{O} \rightarrow \mathrm{CO}+\mathrm{H}_{2} \\
& \mathrm{C}+2 \mathrm{H}_{2} \rightarrow \mathrm{CH}_{4} \\
& \mathrm{CO}+\mathrm{H}_{2} \mathrm{O} \rightarrow \mathrm{CO}_{2}+\mathrm{H}_{2} \\
& \mathrm{CH}_{4}+\mathrm{H}_{2} \mathrm{O} \rightarrow \mathrm{CO}+3 \mathrm{H}_{2} \\
& \mathrm{CH}_{4}+\mathrm{CO}_{2} \rightarrow 2 \mathrm{CO}+2 \mathrm{H}_{2}
\end{aligned}
$$

This is an Open Access article distributed under the terms of the Creative Commons Attribution License 2.0, which permits unrestricted use, distribution, and reproduction in any medium, provided the original work is properly cited. 
Typically the formation of char from devolatization or pyrolysis is considered to be the most important step in the thermochemical conversion of lignocellulosic biomass. Furthermore, biomass char is highly porous (pore sizes $>30 \mu \mathrm{m}$ ) and consists of hydrocarbons and alkali metal constituents which reportedly contribute to the reactivity of biomass chars [1, 2]. Hence a comprehensive understanding of the thermochemical process is required to improve the process dynamics and scale up for future applications.

This study is aimed at examining the thermal decomposition behavior of Char produced from the air gasification of pulverized Empty Fruit Bunch (EFB) briquette in a fixed bed tubular using thermogravimetric analysis (TGA). The properties of EFB briquette as a viable fuel for thermochemical conversion processes have been investigated [3-5]. The entire procedure and schematic process of the air gasification of EFB briquette and char production in a fixed tubular reactor is described in our previous study [6].

\section{Experimental}

The char was produced from the air gasification of EFB briquettes obtained from Felda Semenchu Sdn Bhd, Johor Bahru, Malaysia. The EFB briquette was gasified in a fixed bed tubular reactor from $600{ }^{\circ} \mathrm{C}$ to $700{ }^{\circ} \mathrm{C}$ and equivalence ratio $(E R)=0.4$. Subsequently, the decomposition behavior of the EFB briquette and char were examined via TGA analysis.

Using a thermogravimetric analyzer (TGA Model Mettler Toledo TGA/SDTA 851) $5.09 \mathrm{mg}$ of the EFB briquette was placed in an aluminum sample holder and heated from $28{ }^{\circ} \mathrm{C}$ to $1000{ }^{\circ} \mathrm{C}$ at $10{ }^{\circ} \mathrm{C}$ per min heating rate using nitrogen $\left(\mathrm{N}_{2}\right)$ (flow rate of $25 \mathrm{ml} / \mathrm{min}$ ) as sweeping gas. The procedure was repeated for $5.18 \mathrm{mg}$ of char sample. The theromograms obtained were subsequently analyzed to examine the thermal decomposition of the samples on a comparative basis.

\section{Results and Discussion}

\subsection{Char waste from air gasification}

Table 1 presents an overview of the amount of char produced from the air gasification of EFB briquette from $600{ }^{\circ} \mathrm{C}$ to $700{ }^{\circ} \mathrm{C}$ in a fixed bed tubular reactor. The results indicate that $18 \%$ to $22 \%$ char is produced during the air gasification of EFB briquette in the reactor.

Table 1. Effect of temperature on amount of char produced.

\begin{tabular}{|c|c|c|}
\hline Temperature $\left({ }^{\circ} \mathbf{C}\right)$ & Char (g) & Char/Feed (\%) \\
\hline 600 & 0.57 & 22.80 \\
\hline 625 & 0.55 & 22.00 \\
\hline 650 & 0.52 & 20.80 \\
\hline 675 & 0.46 & 18.40 \\
\hline 700 & 0.56 & 22.40 \\
\hline
\end{tabular}

From Table 1, it can be observed that the char produced decreased by $8 \%$ as gasification temperature increased from $600{ }^{\circ} \mathrm{C}$ to $650{ }^{\circ} \mathrm{C}$. The decrease in char with increasing temperature can be attributed to effect of high temperatures on the main char decomposition reactions such as the Boudouard reaction (Eqn 3) and Water-gasification reaction (Eqn 4).

According to Le Chatelier's principle, the endothermic nature of the reactions is influenced by high temperatures which favor the decomposition of char. In addition, exothermic char oxidation 
reactions (Eqns $1 \&$ 2) also contribute to the decomposition of char producing the heat required for gasification. However, the increase in the amount of char produced from $650{ }^{\circ} \mathrm{C}$ to $700{ }^{\circ} \mathrm{C}$ which deviates from the expected trend.

\subsection{Thermogravimetric analysis (TGA)}

The TGA curves for EFB briquette and Char is presented in Fig. 1. As can be observed the TGA curve of Char is identical in shape to part D of the EFB briquette curve. This is a confirmation that the Part $\mathrm{D}$ of the EFB Briquette is due to char degradation.

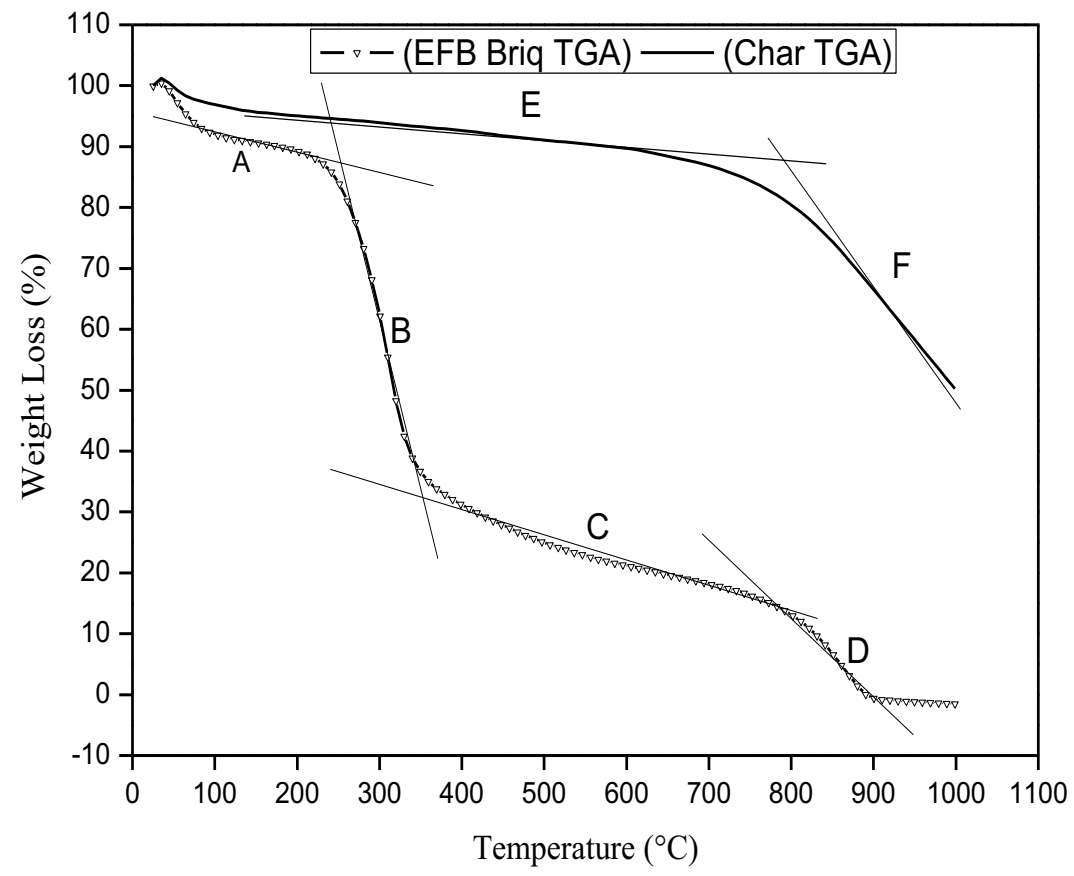

Figure 1. TGA curves for EFB briquette and Char.

Table 2 presents the temperature profiles of EFB Briquette and Char including weight loss ( $m g$ and $\%$ ). The results also indicate that the decomposition of EFB Briquette occurs in four stages; drying, devolatization, reduction and char degradation (A, B, C \& D Fig. 1).

Table 2. Temperature profiles of EFB Briquette and Char decomposition.

\begin{tabular}{|c|c|c|c|c|}
\hline & $\begin{array}{c}\text { Stage of } \\
\text { decomposition }\end{array}$ & $\begin{array}{c}\text { Temperatur } \\
\mathrm{e} \\
\left({ }^{\circ} \mathrm{C}\right)\end{array}$ & $\begin{array}{c}\text { Weight } \\
\text { Loss (mg) }\end{array}$ & $\begin{array}{c}\text { Weight } \\
\text { Loss (\%) }\end{array}$ \\
\hline A & Drying/Ignition & $28-250$ & 0.82 & 16.11 \\
\hline B & Devolatization & $251-359$ & 2.51 & 49.31 \\
\hline C & Reduction & $360-782$ & 1.04 & 20.43 \\
\hline D & $\begin{array}{c}\text { EFB Char } \\
\text { Degradation }\end{array}$ & $783-998$ & 0.66 & 13.17 \\
\hline E & Char Degradation I & $28-772$ & 0.89 & 17.18 \\
\hline F & Char Degradation II & $772-998$ & 1.69 & 32.63 \\
\hline
\end{tabular}


Furthermore, the results indicate the complete thermal decomposition of EFB briquette occurs within the chosen temperature range. The most significant weight loss $2.51 \mathrm{mg}$ or $49.31 \%$ occurred during the devolatization stage (B) indicating this may be the rate determining step of the process. In addition, the EFB char degradation stage (D) resulted in $13 \%$ weight loss of the sample. Conversely, the decomposition of char occurs in two stages; char degradation I \& II (E\&F). Hence only $\sim 50 \%$ of the char was decomposed during thermal analysis from $28{ }^{\circ} \mathrm{C}$ to $1000{ }^{\circ} \mathrm{C}$. The weight loss during char degradation stage I resulted in $17.18 \%$ loss in the weight of the sample. The observed weight loss during this stage of char decomposition is similar to the EFB briquette sample.

Hence, it we can conclude that the char degradation stage may intrinsically be the removal of water originating from the hygroscopic nature of the carbon based char. The hygroscopic nature of char has reported extensively [7, 8]. However, the complete decomposition of char requires temperatures above $1000{ }^{\circ} \mathrm{C}$ as shown by the incomplete thermogram and peak in Fig.s 1and 2 respectively.

\subsection{Differential Thermogravimetric analysis (DTG)}

The DTG curves for EFB briquette and char are presented in Fig. 2. The DTG curve for EFB briquette shows two small peaks labelled $G$ and $I$ and one large symmetric peak labelled $H$. Conversely, only one peak labelled J in Fig. 2 was observed for the Char sample.

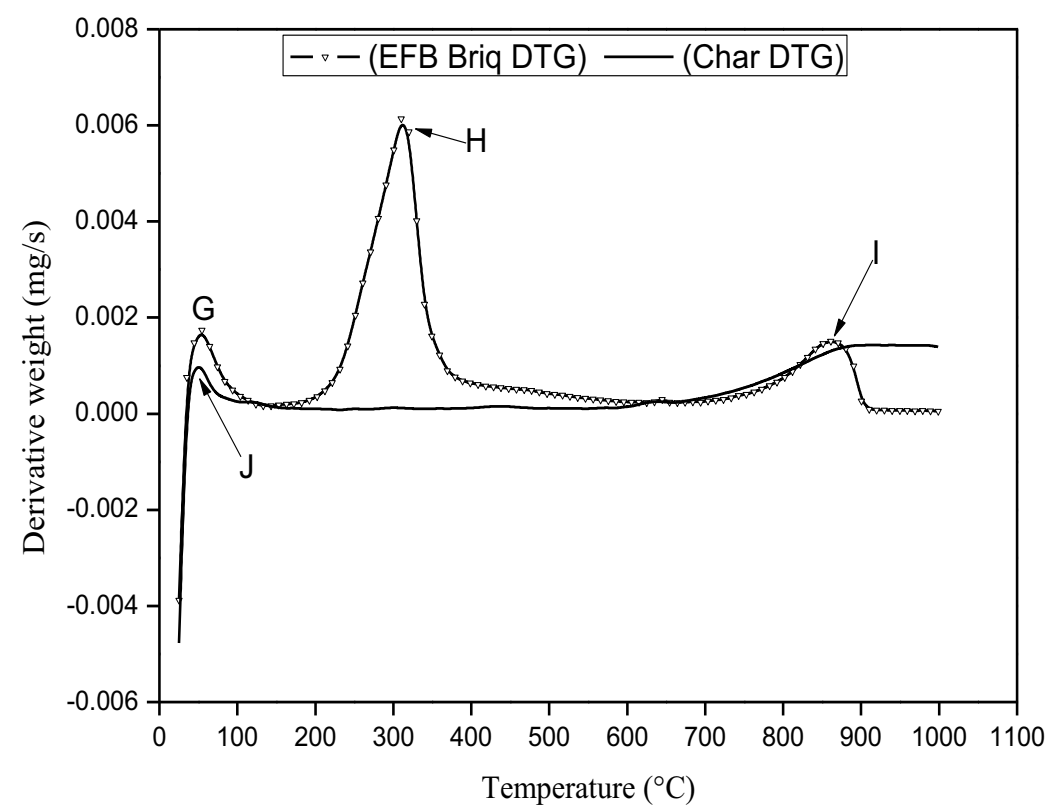

Figure 2. DTG curves for EFB briquette and Char.

Table 3. Peak Temperature Profiles of EFB Briquette and Char.

\begin{tabular}{|c|c|c|c|}
\hline \multirow{3}{*}{ Sample } & $\begin{array}{c}\text { Peak } \\
\text { Designation }\end{array}$ & $\begin{array}{c}\text { Temperature range } \\
{ }^{\circ} \mathrm{C}\end{array}$ & $\begin{array}{c}\text { Peak decomposition } \\
\text { temperature }\left({ }^{\circ} \mathrm{C}\right)\end{array}$ \\
\cline { 2 - 4 } & $\mathrm{G}$ & $28-153$ & 55 \\
\cline { 2 - 4 } & $\mathrm{H}$ & $153-400$ & 311 \\
\cline { 2 - 4 } ChB Briquette & $\mathrm{I}$ & $700-900$ & 856 \\
\hline \multirow{2}{*}{ Char } & $\mathrm{J}$ & $28-153$ & 55 \\
\hline
\end{tabular}


Table 3 presents the peak temperature profiles of EFB briquette and Char deduced from the DTG curves in Fig. 2. The peaks $G$ for EFB briquette, and $J$ for char, are identical in shape and symmetry with a peak decomposition temperature of $55{ }^{\circ} \mathrm{C}$ which is due to drying at temperatures below $150{ }^{\circ} \mathrm{C}$. However the difference in size between the peaks indicates that both samples have different moisture content. The large symmetric peak $H$ observed has a peak decomposition temperature of $311^{\circ} \mathrm{C}$ although the peak decomposition temperature of $856^{\circ} \mathrm{C}$ was observed in the peak $I$.

\section{Conclusion}

This study was aimed at examining the thermal decomposition behavior of Char and Empty Fruit Bunch (EFB) briquette using thermogravimetric analysis (TGA). The results showed that char decreased from $22 \%$ to $18 \%$ with increase in temperature from $600{ }^{\circ} \mathrm{C}$ to $700{ }^{\circ} \mathrm{C}$. In addition, three DTG peaks for EFB briquette and one peak for Char were observed during thermal analysis. Complete thermal decomposition of EFB briquette occurred within the chosen temperature range whereas only $50 \%$ of char thermally decomposed during thermal analysis.

\section{Acknowledgment}

The financial support of the Ministry of Higher Education (MOHE) through the GUP Grant VOT No.05H04 and the International Doctoral Fellowship (IDF) from Universiti Teknologi Malaysia (UTM) is greatly appreciated.

\section{References}

1. P. Basu, Biomass Gasification and Pyrolysis: Practical Design and Theory. Associated Press for Elsevier Inc., U.K, (2010).

2. J. M. Encinar, J. F. Gonzalez, J. J. Rodriguez, M. J. Ramiro, Fuel 80 (14) 2025-2036 (2001).

3. B.B. Nyakuma, A. Johari, A. Ahmad, J. Appl Sci 12 (24) 2527-2533, (2012).

4. B.B. Nyakuma, A. Johari, A. Ahmad, T. A. T. Abdullah, Energy Procedia (2014) (in press).

5. B.B. Nyakuma, A. Johari, A. Ahmad, T. A. T. Abdullah, Jurnal Teknologi 67 (3) 79-82 (2014).

6. B.B. Nyakuma, M. Mazangi, T. A. T. Abdullah, A. Johari, A. Ahmad, O. Oladokun, Appl Mechanics Mat (2014) (in press).

7. H. Weingartner, N. Saathoff, V. Streit, M. Lavanchy, U. Schnaiter, U. Matter, U. Baltensperger, J. Aerosol Sci, 31(1) 987-988, (2000).

8. V. C. Srivastava, M. M. Swamy, I. D. Mall, B. Prasad, I.M. Mishra, Colloids and Surfaces A, 272:1-2, 89-104, (2006). 